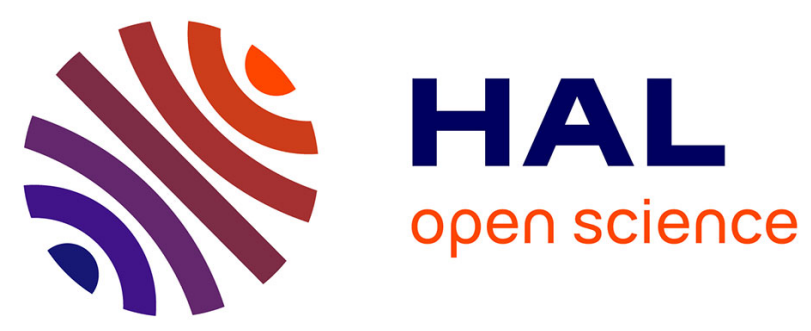

\title{
Plasma Retinol Concentration Is Mainly Driven by Transthyretin in Hemodialysis Patients.
}

Stanislas Bataille, Jean-François Landrier, Julien Astier, Sylvie Cado, Jérôme

Sallette, Marianne Serveaux, Stéphane Burtey, Julien Cohen, Charlène

Tournier, Franck Tourniaire, et al.

\section{To cite this version:}

Stanislas Bataille, Jean-François Landrier, Julien Astier, Sylvie Cado, Jérôme Sallette, et al.. Plasma Retinol Concentration Is Mainly Driven by Transthyretin in Hemodialysis Patients.. Journal of Renal Nutrition, 2017, 27 (6), pp.395-401. 10.1053/j.jrn.2017.05.001 . hal-01771210

\section{HAL Id: hal-01771210 \\ https://hal-amu.archives-ouvertes.fr/hal-01771210}

Submitted on 9 May 2018

HAL is a multi-disciplinary open access archive for the deposit and dissemination of scientific research documents, whether they are published or not. The documents may come from teaching and research institutions in France or abroad, or from public or private research centers.
L'archive ouverte pluridisciplinaire HAL, est destinée au dépôt et à la diffusion de documents scientifiques de niveau recherche, publiés ou non, émanant des établissements d'enseignement et de recherche français ou étrangers, des laboratoires publics ou privés.

\section{다(1)(2)}

Distributed under a Creative Commons Attribution - ShareAlikel 4.0 International 


\section{Plasma retinol in hemodialysis patients}

1 Plasma retinol concentration is mainly driven by transthyretin in hemodialysis patients.

Bataille S, Landrier JF, Astier J, Cado S, Sallette J, Serveaux M, Burtey S, Cohen J, 3 Tournier C, Tourniaire F, Darmon $P$

4

$5 \underline{\text { Abstract }}$

6 Background

7 Micronutrients deficiencies in hemodialysis patients are due to low dietary intakes and

8 intradialytic losses for hydrophilic micronutrients. Conversely, lipophilic non-dialyzable

9 compounds might accumulate due to a lack of elimination through renal metabolism or

10 dialysis. Other compounds have complex metabolism: their concentration is not explained by

11 these phenomenons.

12 Study design

13 Monocentric observational longitudinal study

14 Subjects

15123 hemodialysis patients

16 Main outcome measure

17 Plasma concentration of lipophilic micronutrients: retinol and its two cotransporters

18 transthyretin and retinol binding protein 4 , tocopherol, and carotenoids ( $\alpha$ - and $\beta$-carotene, $\beta$ -

19 cryptoxanthin, lycopene, lutein, zeaxanthin) and all factors associated with one-year mortality

\section{Results}

21 Within the 123 patients of the study, median age [IQR] was 77.5[69.5-84.5] years and 58.5\%

22 were male. Median retinol plasma concentration was 4.07[2.65-5.51] $\mu \mathrm{mol} / \mathrm{L}$, and $91.9 \%$ of

23 patient had high plasma retinol concentrations. In monovariate analysis, retinol levels were

24 inversely correlated with mortality ( $\mathrm{HR}=0.57[0.45-0.72] ; \mathrm{p}<0.001)$. This effect remained

25 significant after adjustment with several parameters. Nevertheless, the correlation between retinol and mortality disappeared as soon as transthyretin was added in the statistical model, suggesting an effect of transthyretin as confusing bias. 


\section{Plasma retinol in hemodialysis patients}

26 Median tocopherol plasma concentration was 34.8[28.3-42.9] $\mu \mathrm{mol} / \mathrm{L}$ and $72.4 \%$ of patients

27 had high plasma tocopherol concentration. Neither tocopherol plasma levels, nor carotenoids

28 concentrations were correlated with death in multivariate analysis.

\section{Conclusions}

30 In hemodialysis patients, the correlation between retinol plasma concentration and mortality

31 represents the nutritional status but not a direct biological effect of retinol. Retinol is only a

32 surrogate predictor of mortality. It might not represent vitamin A levels, but likely the

33 transthyretin level. Plasma retinol levels should be interpreted cautiously in hemodialysis

34 patients.

35

36

37 Keywords: chronic hemodialysis, retinol, transthyretin, micronutrients, tocopherol, vitamin A 38

39 Conflict of Interest Statement and Funding sources: None 


\section{Plasma retinol in hemodialysis patients}

\section{Introduction}

42 Protein energy wasting syndrome affects 30 to $60 \%$ of hemodialysis patients (HD) and

43 contributes to high morbidity and mortality rates in this specific population [1]. Yet, in daily

44 practices, very little concern is made about micronutrients (i.e. vitamins and trace elements)

45 which are implicated in many metabolic functions including regulation of oxidative stress, or

46 modulation of the immune system [2].

47 Micronutrients deficiencies in HD patients are due to low dietary intakes, but also from

48 intradialytic losses for small hydrophilic micronutrients, and conversely micronutrients

49 accumulation, to a lack of elimination through renal metabolism or dialysis techniques for

50 some lipophilic or non-dialyzable compounds [2,3]. Nevertheless, some compounds have

51 more complex metabolism and their plasma concentration is not only explained by these

52 simple phenomenons.

53 In the lack of supplementation, some micronutrient plasma levels are low in HD patients

54 compared to healthy subjects: thiamine (vitamin B1), niacin (vitamin B3), pyridoxine 55 (vitamin B6), folates (vitamin B9), ascorbic acid (vitamin C), vitamin D,selenium, zinc and 56 manganese [2, 4].Other micronutrient plasma levels, on the contrary, are high, especially

57 retinol (vitamin A)but also cadmium, chromium, copper, lead, and vanadium [4, 5].Finally, 58 for some micronutrients, like tocopherol (vitamin E), plasma levels have been described as

59 low, normal or high according to different studies. [2].

60 In HD patients, plasma retinol levels have been described to be inversely related to mortality

61 rate in two observational prospective studies [5, 6]. However, pathophysiological explanations

62 for the patients' benefit of survival in case of high concentrations of plasma retinol are not

63 clear. In another study, high tocopherol levels were associated with a better survival, but this

64 effect disappeared with adjustment with other parameters [7]. To our best knowledge, no 


\section{Plasma retinol in hemodialysis patients}

65 study has assessed the link between carotenoids plasma concentration and survival in HD 66 patients.

67 In this study, we aimed 1/ to assess plasma concentrations of lipophilic micronutrients: retinol 68 (and its physiological partners: retinol binding protein 4 (RBP4) and transthyretin), 69 tocopherol, and carotenoids; and 2/ to analyze if these plasma concentrations are predictive of 70 subsequent mortality in HD patients.

71

72

73

74 


\section{Plasma retinol in hemodialysis patients}

\section{Methods}

\section{Subjects and study design}

77 We conducted a retrospective longitudinal study on all patients from our HD center from July

782014 to July 2015. All patients with data available regarding micronutrients were included,

79 except for pregnant women or patients aged $<18$ years. Written information was provided to

80 all patients, and all gave consent for their personal data to be used for research purposes.

81 According to French law, it is neither necessary nor possible to obtain approval from an

82 ethical committee (in French CPP, Comité de Protection des Personnes) for this type of non-

83 interventional study. Moreover, CPPs are not entitled to issue waivers of approval for this type

84 of study. Nevertheless, this study obtained approval from the Health Research Data

85 Processing Advisory Committee (in French CCTIRS, Comité consultatif sur le traitement de

86 l'information en matière de recherche dans le domaine de la santé; ref 15.684bis) and the

87 French National Commission for Data Protection and Liberties (CNIL).

89 Clinical, biological, and hemodialysis parameters

90 The following data were collected from the patients' medical files: age, gender, diabetes

91 mellitus, nephropathy, height, post-dialysis weight, vascular access. Evaluation of daily urine

92 output was based on oral questioning of the patients and was therefore semi-quantitative:

$93 \geq 500 \mathrm{~mL} / \mathrm{d}$ or $<500 \mathrm{~mL} / \mathrm{d}$. Body mass index (BMI) was calculated as post-dialysis weight

94 after the mid-week session in kilograms divided by squared height in meters. Survival was

95 assessed for all patients at one year.

96 Dialysis parameters were recorded at the mid-week session, and biological analyses were all

97 performed at the start of this hemodialysis session. Dialysis dose was estimated by a single-

98 pool Kt/V (spKt/V), as recommended by Daugirdas et al. [8]. The ESRD adapted Charlson

99 Comorbidity Index was performed for each patient [9]. 


\section{Plasma retinol in hemodialysis patients}

101 Biological data

102 Albumin, transthyretin, predialysis creatinine and urea as well as C-reactive protein which are

103 performed in routine practice in our hemodialysis center were recorded from patient's medical 104 files. Transthyretin was dosed using an immunoturbidimetry assay (ADVIA ${ }^{\circledR} 1800$ Clinical 105 Chemistry System, Siemens, France). Albumin was dosed in serum using bromocresol green 106 assay (ADVIA ${ }^{\circledR} 1800$ Clinical Chemistry System, Siemens, France).

108 Lipophilic vitamins and carotenoids quantification

109 The assays of carotenoids ( $\alpha$ - and $\beta$-carotene, $\beta$-cryptoxanthin, lycopene, lutein, zeaxanthin)

110 and vitamins were carried out by high-pressure liquid chromatography (HPLC) after 111 extraction by organic solvents [10].

112 RBP4 quantification was performed using dedicated ELISA kits (Quantikine Elisa, R\&D 113 systems, France) according to the manufacturer's instructions.

$115 \underline{\text { Statistical analyses }}$

116 Kaplan Meier tests were performed to assess association between transthyretin and mortality, 117 as well as retinol and mortality. Univariate linear models were used to assess association 118 between retinol and transthyretin, retinol and RBP4, and predialysis serum creatinine and 119 RBP4. Cox models were used to determine factors associated with mortality. In a first step, 120 variables with a statistical p-value of $<0.10$ in the univariate analysis were considered eligible 121 for inclusion in the multivariate analysis. In a second step, using a descending stepwise 122 method, variables with a $\mathrm{p}<0.05$ in the multivariate analysis were retained within the final 123 model. Results are shown as their medians [IQR] or percentages. Statistical analyses were 124 performed with IBM SPSS 15.0 software. 
Plasma retinol in hemodialysis patients

125 


\section{Plasma retinol in hemodialysis patients}

\section{Results}

127 Studied population

128 A total of 123 HD patients was included in this observational study. Median age [IQR] was

12977.5 [69.5-84.5] years and 58.5\% of patients were male (Table 1). Within the studied 130 population, $49.6 \%$ of patient had diabetes mellitus. All patients had end-stage renal failure and

131 had been treated with conventional hemodialysis with high-flux membranes for 28.6 [12.413276.6 ] months. Residual diuresis of $\geq 500 \mathrm{~mL}$ was present in $53.3 \%$ of patients.

133 The etiology for the primary cause of renal failure was diabetic nephropathy in $30.1 \%$ of 134 patients, vascular nephropathy in $26.8 \%$, chronic interstitial nephritis in $11.4 \%$, non-diabetic 135 glomerular disease in 4.1\%, autosomal dominant polycystic kidney disease in 1.6\%, other in 136 4.9\%, and unknown in 21.1\%.

137 Most patients underwent at least 12 hours per week HD, distributed among three sessions. 138 Median spKt/V [IQR] was 1.56 [1.43-1.74]. Vascular access was a native fistula in 63.4\% of 139 patients, an arteriovenous graft in $18.7 \%$ and a catheter in $17.9 \%$.

140 Nutritional parameters are reported in Table 1. Briefly, median BMI was 25.8 [22.5$14129.3] \mathrm{kg} / \mathrm{m}^{2}$, and median albumin was 38.0 [34.0-40.0] g/L.

143 Transthyretin and RBP4

144 Median transthyretin was 270 [200-330] mg/L and median RBP4 was 90.8 [59.3-115.8] mg/L. 145 Only 37.3\% of patients had a normal transthyretin level (i.e. $\geq 300 \mathrm{mg} / \mathrm{L}$ ); 82.8\% had plasma 146 concentrations of RBP4 above the higher normal threshold, 17.2\% had normal levels and no 147 patient had low levels.Albumin was also correlated with transthyretin $\left(r^{2}=0.49 ; p<0.001\right)$. 148 RBP4, which accumulates during chronic renal failure, was correlated with transthyretin $149\left(r^{2}=0.31 ; \mathrm{p}<0.001\right)$ and with predialysis serum creatinine $\left(\mathrm{r}^{2}=0.19 ; \mathrm{p}<0.001\right)$. 


\section{Plasma retinol in hemodialysis patients}

151 Retinol plasma concentration

152 Median retinol plasma concentration was 4.07 [2.65-5.51] $\mu \mathrm{mol} / \mathrm{L}$ (Table 1). Among the 123 153 patients 91.9\% had plasma retinol concentrations above the higher normal threshold, only

154 8.1\% had normal levels and 0.8\% had a low level.

155 Retinol plasma concentration was well correlated with its two plasma transporters 156 transthyretin $\left(\mathrm{r}^{2}=0.72 ; \mathrm{p}<0.001\right)$ and $\mathrm{RBP} 4\left(\mathrm{r}^{2}=0.26 ; \mathrm{p}<0.001\right)$ as well as with albumin $157 \quad\left(\mathrm{r}^{2}=0.36 ; \mathrm{p}<0.001\right)$.

158 In monovariate analysis, lower retinol plasma levels were correlated with mortality (HR=0.57 159 [0.45-0.72]; $\mathrm{p}<0.001)$ (Table 1, Figure 1). This effect remained significant after adjustment 160 with several parameters (Table 3), but the correlation between retinol and mortality 161 disappeared as soon as transthyretin was added to the statistical model, suggesting an effect of 162 transthyretin as confusing bias.

164 Tocopherol

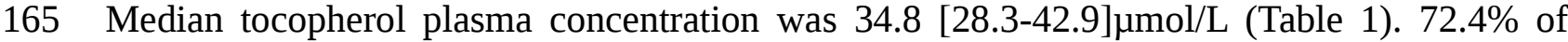
166 patients had high plasma tocopherol concentration, $27.6 \%$ had normal levels and only $2.4 \%$ 167 had low tocopherol levels. In monovariate analysis, lower tocopherol plasma levels were 168 correlated with mortality $(\mathrm{HR}=0.96$ [0.94-0.99]; $\mathrm{p}<0.003)$ (Table 1$)$. This effect remained 169 significant after adjustment with albumin and c-reactive protein, but disappeared after 170 adjustment with other parameters (Table 3). Tocopherol was correlated with triglycerides 171 plasma concentration (data not shown), thus, to assess the effect of free tocopherol on 172 mortality, the relationship between the tocopherol/triglycerides ratio and mortality was

173 studied. Median tocopherol/TG concentration was 20.7 [15.8-30.2] $\mu \mathrm{mol} / \mathrm{mmol}$. This ratio 


\section{Plasma retinol in hemodialysis patients}

174 was correlated with mortality in monovariate analysis, but this correlation was no longer

175 significant after adjustment with albumin (Table 1).

176

177 Carotenoids

178 Plasma concentrations of carotenoids are reported in Table 1. No normal values are available

179 for these compounds. In monovariate analysis, only lycopene (HR=0.52 [0.31-0.88]; $\mathrm{p}=0.02)$

180 and lutein $(\mathrm{HR}=0.04$ [0.01-0.84]; $\mathrm{p}=0.04)$ were associated with mortality. However, this effect

181 was no longer significant after adjustment with albumin.

183 Survival

184 At one year of follow-up, $26.8 \%$ of patients had died ( $\mathrm{n}=33$ patients). Causes of death are

185 reported in Table 2. They were mainly cardiac (27.3\%), infectious (18.2\%), cancer (15.2\%),

186 withdrawal of dialysis (15.2\%) and vascular causes (12.1\%).

187 Besides lipophilic vitamins and carotenoids, the parameters associated with mortality in 188 monovariate analysis were: age $(\mathrm{HR}=1.03$ ]1.00-1.07]; $\mathrm{p}=0.04)$, adapted Charlson 189 comorbidity index $(\mathrm{HR}=1.19$ [1.07-1.31]; $\mathrm{p}=0.001)$, presence of a catheter for the vascular 190 access (HR2.99 [1.45-6.17]; $\mathrm{p}=0.003)$, albumin ( $\mathrm{HR}=0.88$ [0.83-0.93]; $\mathrm{p}<0.001)$, transthyretin 191 (HR=0.90 [0.87-0.94]; $\mathrm{p}<0.001)$, predialysis creatinine $(\mathrm{HR}=0.99$ [0.99-0.99]; $\mathrm{p}=0.002)$ and 192 predialysis urea $(\mathrm{HR}=0.93$ [0.88-0.99]; $\mathrm{p}=0.03)$. C-reactive protein level was at the limit of 193 significance. 


\section{Plasma retinol in hemodialysis patients}

196

197

\section{Discussion}

In this study, we confirmed that hemodialysis patients display high plasma retinol and RBP4concentrations, and that the highest concentrations of retinol were correlated with an improved survival in monovariate analysis. A new insight of our study was that this correlation disappears when retinol concentration was adjusted with transthyretin concentration, which suggests that high retinol plasma concentration is only a surrogate marker of higher concentration of transthyretin, which reflects a good nutritional status of hemodialysis patients.

To understand this new insight, one must be familiar with retinol physiology. Dietary sources of vitamin A include its provitamin, beta-carotene which is found in vegetable sources, and its active forms -retinol, retinal and retinoic acid- which are found in animal sources. Retinol storage is mainly in the liver stellar cells as retinyl esters. In the plasma, retinol which is a lipophilic compound is linked to a transport complex consisting of RBP4 and transthyretin -also known as prealbumin - forming a complex characterized by an equimolecular ratio of $1: 1: 1[11]$

RBP4 is a single polypeptide chain protein, synthesized in the liver, which binds and transports retinol to the target organs. It is a strong signal for stellar cells to remove retinol into the plasma and therefore, retinol plasma concentration is highly regulated by RBP4[12]. During renal failure, RBP4, which has a renal degradation, accumulates. The high concentration of retinol is mainly due to RBP4 accumulation which is a signal for liver cells to remove retinol in the plasma. In our study, median retinol plasma concentration was 4 times higher than normal values, which was in accordance with previous literature reporting retinol concentrations to be 3 to 4 times higher in HD patients than in healthy subjects [13-15].

RBP4 is a $21 \mathrm{kDa}$ molecule and is thus considered as a middle size ( $>500 \mathrm{Da}$ ) protein bound uremic toxin [16, 17]. In hemodialysis patients, convective therapy using online 


\section{Plasma retinol in hemodialysis patients}

221 hemodiafiltration improved RBP4 removal compared to hemodialysis with high-flux

222 membranes, as attended for a middle size uremic toxin, whereas membrane permeability only

223 provided a slight removal increase [18]. Nevertheless, a 4-hour high volume post-dilution

224 hemodiafiltration session only partly removes accumulated RBP4 with a reduction ratio of

225 less than 30\% [18]. Thus, plasmatic RBP4 concentrations in HD patients are usually 2 to 2.5

226 times higher than in healthy subjects [16]. Our observation was very similar: median RBP4

227 concentration was of 90.8 [59.3-115.8] $\mathrm{mg} / \mathrm{L}$ where upper normal threshold of the dosing

228 technique was $48.6 \mathrm{mg} / \mathrm{L}$.

229 In HD patients, transthyretin concentration is representative of the nutritional status, 230 exhibiting significant relationships with energy and protein intake as well as with fat stores

231 and lean body mass. In addition to its relationship with nutritional status, transthyretin is 232 involved in the inflammatory response and its serum concentration is negatively correlated

233 with inflammatory markers. Serum transthyretin concentrations lower than $300 \mathrm{mg} / \mathrm{l}$ were

234 associated with an increased risk of morbidity and mortality independently from serum 235 albumin [11].

236 In malnourished HD patients, the serum transthyretin/RBP4 ratio is thus highly modified 237 because of a high RBP4 concentration and low transthyretin concentration [13]. We show that 238 in this specific population, retinol is better correlated with transthyretin $\left(\mathrm{r}^{2}=0.72 ; \mathrm{p}<0.001\right)$

239 than RBP4 $\left(r^{2}=0.26\right.$; $\left.p<0.001\right)$. Thus, in patients with a low transthyretin and a high RBP4 240 level, transthyretin, which is necessary to remove retinol from its storage in liver cells, could 241 be the limiting factor for this removal [19]. Another explanation could be that transthyretin 242 which reflects the daily dietary intakes is correlated with vitamin A intakes [3], but this latter 243 is not likely because in plasma, retinol concentration is high.

244 Confusion is often made between plasma concentrations of micronutrients and micronutrient 245 status. Regarding vitamin A, plasma retinol concentration is not representative of the overall 


\section{Plasma retinol in hemodialysis patients}

246 vitamin A stores which are mainly located in the liver. Interestingly, vitamin A accumulation

247 hepatotoxicity might occur with a normal retinol plasma level [20] and in patients with

248 hepatitis C virus, liver fibrosis has been associated with retinol plasma levels increase but

249 lower liver storage of vitamin A [21]. In this latter study, no correlation was found between

250 hepatic tissue retinyl palmitate-a retinyl ester- and plasma retinol concentration. Thus, to

251 assess retinol whole body stores, a liver biopsy analysis is required [21].

252 The link between retinol concentration and mortality reflects only the relationship between 253 transthyretin and mortality. In two previous studies, retinol plasma concentration was

254 correlated with death, even after adjustment with many parameters including nutritional status

255 and RBP4, but these studies did not analyze transthyretin levels which is a key element in

256 retinol physiology [5, 6]. The link between retinol plasma concentration and death is not

257 likely because retinol plasma concentration couldincorrectly reflect the vitamin A status.

258 Moreover, these two studies hypothesize a role of low retinol in a high infection rate in HD

259 patients, but one could argue an opposite relationship in which infection induces inflammation

260 and reduces transthyretin concentration and thus retinol concentration [6].

261 Still, the lack of effect of high retinol concentrations on mortality should not be interpreted as 262 if this substance has no effect. Roehrs et al. reported a study in which higher retinol 263 concentrations were associated with higher superoxide dismutase and catalase activities, but

264 these activities did not prevent lipid peroxidation, hypothesizing a pro-oxidant role of high 265 retinol concentrations [15].

266 Regarding vitamin E, our findings are very similar to what has been reported in literature [7]:

267 plasma concentration of tocopherol and tocopherol/TG are correlated with poor outcomes, but 268 this effect does not resist to adjustment with other parameters and thus, plasma tocopherol 269 concentration is only a surrogate marker of the measured outcome, i.e. death. Identically, 270 plasma carotenoids levels were not independently associated with mortality. 


\section{Plasma retinol in hemodialysis patients}

271 We agree this study suffers some limitations: retrospective analysis, small size and old age of

272 the studied population, monocentric design, lack of follow-up. Our results require

273 confirmation in af large independent cohort of patients. Nevertheless, the strength of the

274 correlation between plasma retinol and transthyretin concentrations is striking.

275 In conclusion, our study reports that in HD patients with low transthyretin, retinol plasma

276 concentration eould might not represent vitamin A levels, but likely the nutritional status of

277 the patients. Its correlation with mortality is could be more linked to the nutritional status

278 rather than a direct biological effect of retinol. 


\section{Plasma retinol in hemodialysis patients}

\section{Practical application}

280 Plasma retinol concentration is only a surrogate marker of mortality and it should be

281 interpreted in the highlight of transthyretin concentration. Plasma retinol levels shouldbe

282 interpreted cautiously in HD patients, as well as for tocopherol: its plasmatic concentration

283 might not represent the whole-body vitamin A. 


\section{Plasma retinol in hemodialysis patients}

284

285

286

287

288

289

290

291

292

293

294

295

296

297

298

299

300

301

302

303

304

305

306

307

\section{References}

1. Fouque D, Kalantar-Zadeh K, Kopple J, et al. A proposed nomenclature and diagnostic criteria for protein-energy wasting in acute and chronic kidney disease. Kidney Int.2008 Feb;73(4):391-8.

2. Chazot C, Jean G, Kopple JD. Can Outcomes be Improved in Dialysis Patients by Optimizing Trace Mineral, Micronutrient, and Antioxidant Status? The Impact of Vitamins and their Supplementation.Semin Dial. 2016 Jan;29(1):39-48.

3. Bataille S, Landrier JF, Astier J, et al. Hemodialysis patients with diabetes eat less than those without: a plea for a permissive diet. Nephrology (Carlton). 2016 Jun 11. Epub ahead of print.

4. Tonelli M, Wiebe N, Hemmelgarn B, et al. Trace elements in hemodialysis patients: a systematic review and meta-analysis. BMC Med. 2009 May 19;7:25.

5. Espe KM, Raila J, Henze A, et al. Impact of vitamin A on clinical outcomes in haemodialysis patients. Nephrol Dial Transplant. 2011 Dec;26(12):4054-61.

6. Kalousová M1, Kubena AA, Kostírová M, et al. Lower retinol levels as an independent predictor of mortality in long-term hemodialysis patients: a prospective observational cohort study. Am J Kidney Dis. 2010 Sep;56(3):513-21.

7. Espe KM, Raila J, Henze A, et al. Low plasma $\alpha$-tocopherol concentrations and adverse clinical outcomes in diabetic hemodialysis patients. Clin J Am Soc Nephrol. 2013 Mar;8(3):452-8.

8. Daugirdas JT. Second generation logarithmic estimates of single-pool variable volume Kt/V: an analysis of error. J Am Soc Nephrol. 1993;4:1205-1213.

9. Hemmelgarn BR, Manns BJ, Quan H, et al. Adapting the Charlson Comorbidity Index for use in patients with ESRD. Am J Kidney Dis. 2003 Jul;42(1):125-132. 


\section{Plasma retinol in hemodialysis patients}

10. Gleize B, Steib M, André M, Reboul E. Simple and fast HPLC method for simultaneous determination of retinol, tocopherols, coenzyme $Q(10)$ and carotenoids in complex samples. Food Chem. 2012 Oct 15;134(4):2560-4.

11. Cano NJ. Metabolism and clinical interest of serum transthyretin (prealbumin) in dialysis patients. Clin Chem Lab Med.2002Dec;40(12):1313-9.

12. Raghu P, Sivakumar B. Interactions amongst plasma retinol-binding protein, transthyretin and their ligands: implications in vitamin A homeostasis and transthyretin amyloidosis. Biochim Biophys Acta.2004Dec 1;1703(1):1-9.

13. Cano N, Di Costanzo-Dufetel J, Calaf R, et al. Prealbumin-retinol-binding-proteinretinol complex in hemodialysis patients. Am J Clin Nutr. 1988 Apr;47(4):664-7.

14. Drewnowski A, Rock CL, Henderson SA, et al.Serum beta-carotene and vitamin C as biomarkers of vegetable and fruit intakes in a community-based sample of French adults. Am J Clin Nutr. 1997 Jun;65(6):1796-802.

15. Roehrs M, Valentini J, Bulcão R, et al. The plasma retinol levels as prooxidant/oxidant agents in haemodialysis patients.Nephrol Dial Transplant. 2009 Jul;24(7):2212-8.

16. Vanholder R, De Smet R, Glorieux G, et al. Review on uremic toxins: classification, concentration, and interindividual variability. Kidney Int. 2003 May;63(5):1934-43.

17. Kabanda A, Goffin E, Bernard A, Lauwerys R, van Ypersele de Strihou C. Factors influencing serum levels and peritoneal clearances of low molecular weight proteins in continuous ambulatory peritoneal dialysis. Kidney Int. 1995 Dec;48(6):1946-52.

18. Krieter DH, Hackl A, Rodriguez A, et al. Protein-bound uraemic toxin removal in haemodialysis and post-dilution haemodiafiltration.Nephrol Dial Transplant. 2010 Jan;25(1):212-8. 


\section{Plasma retinol in hemodialysis patients}

332 19. Ingenbleek Y, Bernstein LH. Plasma Transthyretin as a Biomarker of Lean Body Mass 333 and Catabolic States.Adv Nutr. 2015 Sep 15;6(5):572-80.

334 20. Beste LA, Moseley RH, Saint S, Cornia PB. CLINICAL PROBLEM-SOLVING. Too 335 Much of a Good Thing. N Engl J Med. 2016 Mar 3;374(9):873-8.

336 21. Kataria Y, Deaton RJ, Enk E, et al. Retinoid and carotenoid status in serum and liver among patients at high-risk for liver cancer. BMC Gastroenterol. 2016 Feb 338 29;16(1):30.

339 
Plasma retinol in hemodialysis patients

340

341 Tables

342 Table1: General characteristics and factors associated with death: univariate analysis and adjustment with albumin (n=123 patients).

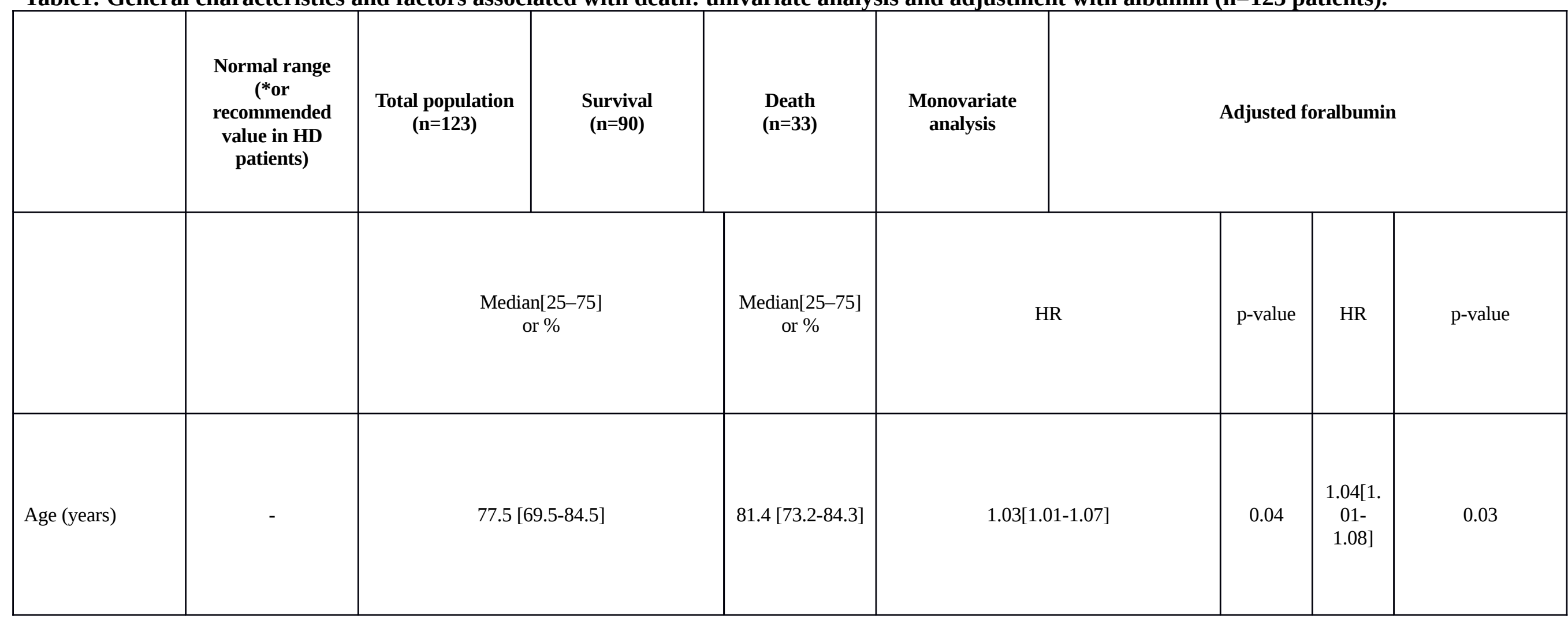


Plasma retinol in hemodialysis patients

\begin{tabular}{|c|c|c|c|c|c|c|c|}
\hline Male gender & - & $58.5 \%$ & $63.6 \%$ & 0.80 [0.39-1.62] & 0.52 & & \\
\hline Diabetes mellitus & - & $49.6 \%$ & $42.4 \%$ & $0.75[0.38-1.50]$ & 0.42 & & \\
\hline $\begin{array}{l}\text { Dialysis vintage } \\
\text { (months) }\end{array}$ & - & 28.6 [12.4-76.6] & $\begin{array}{c}34.9[16.5 \\
{[78.1]}\end{array}$ & 1.00 [0.99-1.01] & 0.84 & & \\
\hline $\begin{array}{l}\text { Charlson } \\
\text { comorbidity index } \\
\text { score }\end{array}$ & - & $6[5-8]$ & 7 [6-9] & 1.19 [1.07-1.31] & 0.001 & $\begin{array}{r}1.22 \\
{[1.09-} \\
1.36]\end{array}$ & $<0.001$ \\
\hline
\end{tabular}


Plasma retinol in hemodialysis patients

\begin{tabular}{|c|c|c|c|c|c|c|c|}
\hline $\begin{array}{l}\text { Diuresis } \geq 500 \\
\mathrm{~mL} / \mathrm{d}\end{array}$ & - & $53.3 \%$ & $48.5 \%$ & 0.76 [0.38-1.51] & 0.43 & & \\
\hline $\begin{array}{r}\text { Vascular access }{ }^{\S} \\
\text { Native fistula } \\
\text { AV graft } \\
\text { Catheter }\end{array}$ & $\begin{array}{l}- \\
- \\
-\end{array}$ & $\begin{array}{l}63.4 \% \\
18.7 \% \\
17.9 \%\end{array}$ & $\begin{array}{l}45.5 \% \\
21.2 \% \\
33.3 \%\end{array}$ & 2.99 [1.45-6.17] & 0.003 & $\begin{array}{c}2.98 \\
{[1.43-} \\
6.20]\end{array}$ & 0.004 \\
\hline $\begin{array}{l}\text { Weight }(\mathrm{kg}) \\
\text { BMI }\left(\mathrm{kg} / \mathrm{m}^{2}\right)\end{array}$ & $\begin{array}{l}- \\
-\end{array}$ & $\begin{array}{l}70.5[59.8-79.4] \\
25.8[22.5-29.3]\end{array}$ & $\begin{array}{l}65.8[53.4-74.4] \\
24.5[21.5-29.3]\end{array}$ & $\begin{array}{l}0.98[0.96-1.01] \\
0.95[0.88-1.02]\end{array}$ & $\begin{array}{l}0.16 \\
0.14\end{array}$ & & \\
\hline $\begin{array}{r}\text { Biological values } \\
\text { Albumin }(\mathrm{g} / \mathrm{L}) \\
\text { Transthyretin } \\
(\mathrm{mg} / \mathrm{L}) \\
\text { Predialysis } \\
\text { creatinine } \\
(\mu \mathrm{mol} / \mathrm{L}) \\
\text { Predialysis urea } \\
(\mathrm{mmol} / \mathrm{L}) \\
\text { C-reactive protein } \\
(\mathrm{mg} / \mathrm{L})\end{array}$ & $\begin{array}{c}>40 \\
>300 \\
- \\
- \\
<0.5\end{array}$ & $\begin{array}{c}38.0[34.0-40.0] \\
270[200-330] \\
594[465-775] \\
18.8[14.6-22.3] \\
8.3[2.7-25.0]\end{array}$ & $\begin{array}{c}34.0[29.0-38.0] \\
190[130-260] \\
516[409-616] \\
17.0[13.5-20.4] \\
14.0[7.4-38.1]\end{array}$ & $\begin{array}{l}0.88[0.83-0.93] \\
0.90[0.87-0.94] \\
0.99[0.99-0.99] \\
0.93[0.88-0.99] \\
1.00[1.00-1.01]\end{array}$ & $\begin{array}{c}<0.001 \\
<0.001 \\
0.002 \\
0.03 \\
0.05\end{array}$ & $\begin{array}{c}- \\
0.91 \\
{[0.86-} \\
0.96] \\
0.99 \\
{[0.99-} \\
1.00] \\
0.96 \\
{[0.89-} \\
1.02]\end{array}$ & $\begin{array}{c}- \\
0.001 \\
0.09 \\
0.19\end{array}$ \\
\hline
\end{tabular}


Plasma retinol in hemodialysis patients

\begin{tabular}{|c|c|c|c|c|c|c|c|}
\hline $\begin{array}{r}\text { Liposolubles } \\
\text { vitamins and } \\
\text { carotenoids } \\
\text { Retinol - vitamin } \\
\text { A ( } \mu \text { mol/L) } \\
\text { Retinol Binding } \\
\text { Protein } 4 \text { (mg/L) } \\
25- \\
\text { hydroxyvitamin D } \\
(\text { ng/mL }) \\
\alpha+\gamma \text { Tocopherol - } \\
\text { Vitamin E } \\
(\mu \mathrm{mol} / \mathrm{L}) \\
\text { Vitamin } \\
\text { E/Triglycerides } \\
(\mu \mathrm{mol} / \mathrm{g}) \\
\text { Lycopen }(\mu \mathrm{mol} / \mathrm{L}) \\
\alpha-C a r o t e n e \\
(\mu \mathrm{mol} / \mathrm{L}) \\
\beta-C a r o t e n e \\
(\mu \mathrm{mol} / \mathrm{L}) \\
\beta \text {-cryptoxanthine } \\
(\mu \mathrm{mol} / \mathrm{L}) \\
\text { Zeaxanthine } \\
(\mu \mathrm{mol} / \mathrm{L}) \\
\text { Lutein }(\mu \mathrm{mol} / \mathrm{L}) \\
\end{array}$ & $\begin{array}{c}0.35-1.75 \\
12.7-48.6 \\
\geq 30 \\
18.0-29.0 \\
- \\
- \\
- \\
- \\
- \\
- \\
-\end{array}$ & $\begin{array}{c}4.07[2.65-5.51] \\
90.8[59.3-115.8] \\
30.8[22.6-38.8] \\
34.8[28.3-42.9] \\
20.7[15.8-30.2] \\
0.93[0.43-1.59] \\
0.11[0.05-0.21] \\
0.24[0.12-0.33] \\
0.08[0.04-0.13] \\
0.02[0.01-0.03] \\
0.23[0.17-0.33]\end{array}$ & $\begin{array}{c}2.60[2.11 \\
{[3.80]} \\
67.2[38.8-93.7] \\
28.0[21.1-36.6] \\
29.2[21.7-38.3] \\
22.3[18.6-33.3] \\
0.56[0.27-1.13] \\
0.11[0.03-0.17] \\
0.17[0.07-0.30] \\
0.06[0.02-0.12] \\
0.01[0.00-0.02] \\
0.20[0.10-0.29]\end{array}$ & $\begin{array}{l}0.57[0.45-0.72] \\
0.98[0.97-0.99] \\
0.98[0.95-1.01] \\
0.96[0.94-0.99] \\
1.03[1.01-1.05] \\
0.52[0.31-0.88] \\
1.02[0.18-5.79] \\
0.57[0.10-3.12] \\
0.01[0.00-4.13] \\
0.00[0.00-3.81] \\
0.04[0.01-0.84]\end{array}$ & $\begin{array}{c}<0.001 \\
0.001 \\
0.20 \\
0.003 \\
0.03 \\
0.02 \\
0.98 \\
0.52 \\
0.14 \\
0.06 \\
0.04\end{array}$ & $\begin{array}{c}0.63 \\
{[0.47-} \\
0.85] \\
0.99 \\
{[0.98-} \\
0.99] \\
\\
0.97 \\
{[0.94-} \\
0.99] \\
1.02 \\
{[0.99-} \\
1.04] \\
0.68 \\
{[0.41-} \\
1.14] \\
\\
\end{array}$ & $\begin{array}{c}0.002 \\
0.02 \\
\\
0.03 \\
0.14 \\
0.15\end{array}$ \\
\hline
\end{tabular}

343 BMI: Body mass index. AV graft: arteriovenous graft.

$344 *$ Recommended values for hemodialysis patients are provided according to European Best Practice Guidelines Guideline on Nutrition [1]

$345 \S$ Comparison is for (Native fistula + AV graft) versus Catheter. 
Plasma retinol in hemodialysis patients

347 Table 2 : Causes of death.

\begin{tabular}{|c|c|}
\hline Death causes & $\mathbf{N}=33$ \\
\hline & Number (\%) \\
\hline Heart disease & $9(27.3 \%)$ \\
\hline Within which sudden death & $7(21.2 \%)$ \\
\hline Infectious disease & $6(18.2 \%)$ \\
\hline Cancer & $5(15.2 \%)$ \\
\hline Cachexia leading to dialysis stop & $5(15.2 \%)$ \\
\hline Peripheral vascular disease & $4(12.1 \%)$ \\
\hline Within which inferior limb arteritis & $2(6.1 \%)$ \\
\hline $\begin{array}{ll}\text { Stoke }\end{array}$ & $1(3.0 \%)$ \\
\hline Mesenteric ischemia & $1(3.0 \%)$ \\
\hline Hemorrhage & $1(3.0 \%)$ \\
\hline Traffic accident & $1(3.0 \%)$ \\
\hline Unknown & $2(6.1 \%)$ \\
\hline
\end{tabular}




\section{Plasma retinol in hemodialysis patients}

Table 3: Association between plasmatic concentrations of liposolubles vitamins retinol and tocopherol and death at one year: multivariate analysis $(n=123)$.

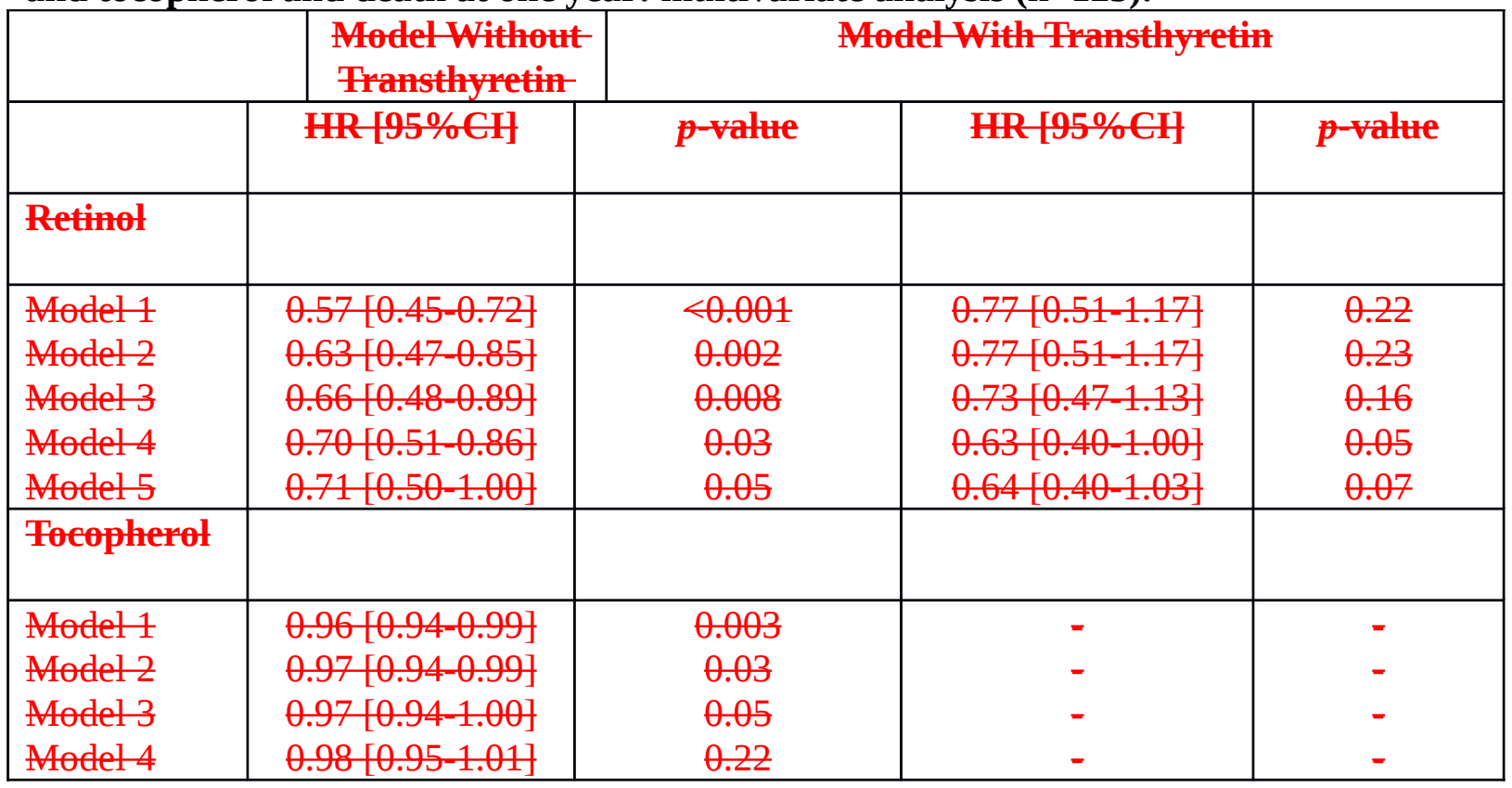

Model 1: Monovariate analysis.

Model 2: Adjusted with albumin.

Model 3: Adjusted with albumin, age, gender, and diabetes mellitus.

Model 4: Adjusted with albumin, age, gender, diabetes mellitus, Charlson comorbidity index seore, and vasenlar aecess.

Model 5: Adjusted with albumin, age, gender, diabetes mellitus, Charlson comorbidity index seore, vaseular aceess and retinol binding protein.

\begin{tabular}{|l|c|c|c|c|}
\hline \multicolumn{2}{|c|}{} & $\begin{array}{c}\text { Model Without } \\
\text { Transthyretin }\end{array}$ & \multicolumn{3}{c|}{ Model With Transthyretin } \\
\hline & HR [95\% CI] & p-value & HR [95\%CI] & $p$-value \\
\hline Retinol & & & & \\
\hline Model 1 & $0.57[0.45-0.72]$ & $<0.001$ & $0.77[0.51-1.17]$ & 0.22 \\
Model 2 & $0.63[0.47-0.85]$ & 0.002 & $0.77[0.51-1.17]$ & 0.23 \\
Model 3 & $0.60[0.44-0.82]$ & 0.001 & $0.77[0.51-1.17]$ & 0.22 \\
Model 4 & $0.63[0.45-0.86]$ & 0.004 & $0.72[0.46-1.13]$ & 0.15 \\
Model 5 & $0.65[0.47-0.91]$ & 0.01 & $0.63[0.39-0.99]$ & 0.05 \\
Model 6 & $0.66[0.46-0.96]$ & 0.03 & $0.63[0.39-1.02]$ & 0.06 \\
\hline Tocopherol & & & & \\
& & & - & - \\
\hline Model 1 & $0.96[0.94-0.99]$ & 0.003 & - & - \\
Model 2 & $0.97[0.94-0.99]$ & 0.03 & - & - \\
Model 3 & $0.97[0.94-0.99]$ & 0.03 & & - \\
Model 4 & $0.97[0.94-1.00]$ & 0.06 & & - \\
Model 5 & $0.98[0.95-1.01]$ & 0.25 & & - \\
\hline
\end{tabular}

CI: confidence interval.

Model 1: Monovariate analysis.

Model 2: Adjusted with albumin.

Model 3: Adjusted with albumin and c-reactive protein.

Model 4: Adjusted with albumin, c-reactive protein, age, gender, and diabetes mellitus. 


\section{Plasma retinol in hemodialysis patients}

364 Model 5: Adjusted with albumin, c-reactive protein, age, gender, diabetes mellitus, Charlson 365 comorbidity index score, and vascular access.

366 Model 6: Adjusted with albumin, c-reactive protein, age, gender, diabetes mellitus, Charlson 367 comorbidity index score, vascular access and retinol binding protein. 
Plasma retinol in hemodialysis patients

370

371 Legends to figures

372 Figure 1

373 Kaplan-Meier curve for the time to all-cause mortality according to retinol plasma

374 concentration quartiles $(\mathbf{n}=\mathbf{1 2 3})$. 
Plasma retinol in hemodialysis patients

375 Figures

376 